\title{
Analisis dan Evaluasi Jabatan pada Perusahaan Tekstil
}

\author{
Ronald Sukwadi ${ }^{1 *}$, Livia Oktevany ${ }^{2}$ \\ $1 *, 2)$ Fakultas Teknik, Jurusan Teknik Industri, Universitas Katolik Indonesia Atmajaya, \\ Jl. Jendral Sudirman 51, Jakarta 12930 \\ email : ronald.sukwadi@atmajaya.ac.id, oktevanylivia23@gmail.com
}

\begin{abstract}
Abstrak
This research presents job analysis and evaluation in order to design salary structure of a textile company. Preliminary interview, questionnaire, observation and focus group discussions were applied for job analysis. In addition, a point factor system and analytical hierarchy process methods were used for doing job evaluation. Job description and job specification and basic salary of each job were produced in this study.
\end{abstract}

Keywords: Analytical Hierarchy Process, Basic Salary, Job Analysis, Job Evaluation, Point Factor System

\begin{abstract}
Abstrak
Penelitian ini menyajikan analisis dan evaluasi jabatan untuk merancang struktur gaji dalam perusahaan tekstil. Wawancara pendahuluan, kuesioner, observasi dan focus group discussion digunakan dalam analisis jabatan. Sebagai tambahan, point factor system dan analytical hierarchy process digunakan dalam evaluasi jabatan. Deskripsi Jabatan, spesifikasi jabatan, dan gaji pokok masing-masing jabatan dihasilkan dalam penelitian ini.

Kata kunci : Analisis Jabatan, Analytical Hierarchy Process, Evaluasi Jabatan, Gaji Pokok, Point Factor System
\end{abstract}

\section{Pendahuluan}

Salah satu faktor yang memegang peranan penting akan perkembangan sebuah perusahaan adalah faktor sumber daya manusia. Sumber daya manusia merupakan aset yang perlu diperhatikan bagi perusahaan, sehingga perusahaan perlu mendorong sumber daya manusia yang ada agar dapat mengembangkan kemampuan serta keterampilan yang dimiliki secara optimal. Salah satu upaya yang dapat dilakukan perusahaan adalah dengan memberikan kompensasi yang adil dan sesuai dengan beban jabatan yang dipegang (Sukwadi, 2014).

Setiap perusahaan memiliki standarnya masing-masing dalam menentukan gaji pekerja. Perusahaan dapat menentukan gaji pokok pekerja berdasarkan hasil penilaian kinerjanya. Menurut Suprianto (2002) terdapat tiga cara dalam menentukan nilai pekerjaan, yaitu analisis prestasi atau pekerjaan, evaluasi jabatan

*Korespondensi Penulis dan melakukan survei harga pekerjaan sejenis pada organisasi lain. Menurut York (2010) analisis pekerjaan merupakan suatu proses yang sistematis untuk mengumpulkan data tentang pekerjaan sehingga deskripsi pekerjaan (persyaratan kerja) dan spesifikasi pekerjaan (persyaratan pekerja) dapat ditulis untuk pekerjaan itu. Menurut Mathis \& Jackson (2006) deskripsi pekerjaan merupakan identifikasi tugas, kewajiban, dan tanggung jawab dari sebuah pekerjaan. Menurut Dessler (2006) spesifikasi pekerjaan merupakan daftar "persyaratan karyawan untuk pekerjaan, yaitu syarat pendidikan, keterampilan, kepribadian, dan seterusnya.

Evaluasi jabatan adalah sebuah proses yang menentukan nilai relatif sebuah jabatan dalam hubungannya dengan jabatan lain. (Sukwadi, 2014). Evaluasi jabatan bertujuan untuk menciptakan konsistensi internal dan konsistensi eksternal dalam pemberian kompensasi atau balas jasa. Sasaran utamanya adalah kepuasan pekerja dan atasan terhadap imbalan yang diba- 
yarkan (Marwansyah, 2010:280). Menurut Pasal 1 Kepmenakertrans No. 49 / Men / IV / 2004 tentang struktur dan skala upah, struktur upah adalah susunan tingkat upah dari yang terendah sampai yang tertinggi atau sebaliknya dari yang tertinggi sampai yang terendah. Sedangkan, skala upah adalah kisaran nilai nominal upah menurut kelompok jabatan.

Dalam kasus ini, evaluasi jabatan pada sebuah perusahaan tekstil kurang baik. Hal ini dikarenakan struktur gaji pokok yang digunakan sebagai standar gaji pokok adalah menurut penilaian dari atasan setiap jabatan, Departemen HRD \& GA (Human Resources Development and General Affair), dan menurut UMR (Upah Minimum Regional). Sehingga, hal ini menjadi sebuah permasalahan penting bagi perusahaan. Permasalahan ini didukung dari hasil wawancara kepada beberapa karyawan perusahaan. Hasil wawancara terhadap pekerja juga dibenarkan oleh Manager HRD \& GA perusahaan tersebut.

Didapatkan bahwa job description atau deskripsi pekerjaan yang dimiliki oleh perusahaan hanya sampai level Manager saja, untuk Operator dan pekerjaan sejenis tidak ada. Selain itu juga tidak adanya spesifikasi pekerjaan secara tertulis. Sedangkan dalam melakukan evaluasi pekerjaan memerlukan deskripsi pekerjaan dan spesifikasi pekerjaan. Oleh karena itu, sebelum melakukan evaluasi jabatan akan dilakukan analisa jabatan terlebih dahulu. Analisa jabatan yang dilakukan akan meliputi usulan deskripsi jabatan dan spesifikasi jabatan dengan melakukan penyebaran kuisioner kepada masingmasing pemegang jabatan, observasi dan membandingkan deskripsi jabatan dan spesifikasi jabatan dengan deskripsi jabatan secara umum. Sedangkan untuk evaluasi jabatan akan menggunakan metode point factor system. Menurut Haris (2014), dalam praktik, metode point factor system paling banyak digunakan. Hal ini disebabkan karena sifat dari metode ini dianggap lebih teliti dalam menentukan nilai suatu jabatan sehingga lebih mendekati rasa keadilan. Selain itu menurut Sukwadi dan Gerald (2010), terdapat beberapa keuntungan dalam menggunakan metode point factor system, yaitu:

1. Penggunaan faktor-faktor tertentu yang telah ditentukan dan dirumuskan terlebih dahulu memaksa para penilai untuk mempertimbangkan unsur jabatan yang sama dalam menilai jabatan;

2. Pemberian nilai angka tidak hanya menunjukkan jabatan mana yang lebih tinggi nilainya, tetapi juga menunjukkan seberapa tinggi nilai itu;

3. Catatan yang jelas tentang putusan para penilai nantinya berguna untuk menjelaskan hasil penilaian kepada para pengawas dan tim penilai yang telah ditunjuk;

4. Sistem ini cenderung memudahkan prosedur penilaian dan memberikan standar yang sama untuk semua penilai;

5. Para penilai mempertimbangkan faktor tertentu yang lebih baik daripada mempertimbangkan jabatan sebagai suatu keseluruhan.

Dalam penggunaan metode point factor system dibantu dengan analytical hierarchy process yang berguna untuk pembobotan. Menurut Saaty (1985) dalam Iwan dan Octavia (2013), analytical hierarchy process adalah sebuah prosedur yang sistematis untuk mewakili elemen-elemen dari masalah secara hirarki. Selanjutnya, untuk membuat usulan struktur gaji pokok digunakan metode regresi linear sederhana dengan mempertimbangkan uji asumsi klasik. Metode regresi linear sederhana ini digunakan untuk mengetahui bagaimana pengaruh variabel independen $(X)$ terhadap variabel dependen $(Y)$ (Sugiyono, 2009). Adapun tujuan penelitian ini meliputi :

1. Melakukan analisis jabatan dalam rangka memperbaiki job description dan job specification.

2. Melakukan evaluasi jabatan dengan menggunakan metode point factor system.

3. Memberikan usulan struktur gaji pokok yang baru bagi masing-masing jabatan berdasarkan hasil analisa jabatan dan evaluasi jabatan

\section{Metode Penelitian}

Objek dalam penelitian ini adalah sebuah perusahaan tekstil, dengan jumlah responden sebanyak 36 orang. Responden yang digunakan merupakan pemegang jabatan di perusahaan tersebut, dengan batasan hanya satu responden setiap pemegang jabatan dan disesuaikan dengan diskusi oleh pihak perusahaan. Langkahlangkah dalam penelitian ini digambarkan dengan alur metode penelitian pada Gambar 1.

\section{Hasil dan Pembahasan}

\subsection{Analisa Jabatan}

Dari analisis jabatan menghasilkan usulan job description dan job specification yang telah disetu- 


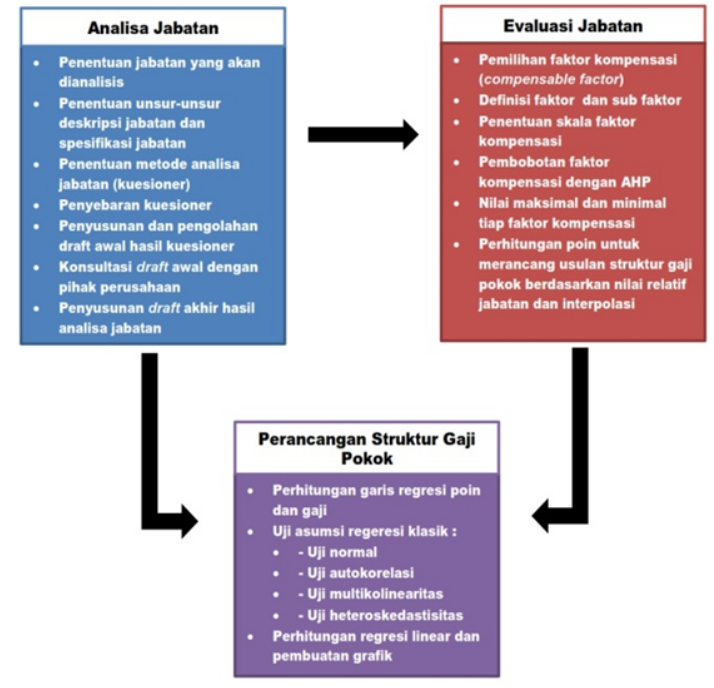

Gambar 1: Alur Metode Penelitian

jui oleh pihak perusahaan. Contoh dari usulan job description dan job specification dapat dilihat pada Tabel 1.

Tabel 1: Contoh Usulan Deskripsi Pekerjaan Operator Produksi

$$
\begin{aligned}
& \text { DESKRIPSI PEKERJAAN } \\
& \text { IDENTIFIKASI PEKERJAAN } \\
& \text { a. Departemen : Produksi } \\
& \text { b. Nama Jabatan : Operator Produksi } \\
& \text { c. Nama Pemegang Jabatan : Giri Wiratno } \\
& \text { d. Atasan Langsung : Kepala Shift Produksi } \\
& \text { e. Bawahan Langsung: }
\end{aligned}
$$

\section{TUJUAN JABATAN}

Bersama Kepala Shift Produksi melaksanakan kegiatan produksi sesuai dengan rencana dan target produksi, serta meningkatkan efisiensi produksi

Selanjutnya deskripsi jabatan usulan ini dianalis dengan job description secara umum, yaitu dari hasil analisis menunjukkan bahwa kelengkapan unsur dalam deskripsi jabatan usulan terstruktur dengan jelas karena telah disesuaikan dengan kebutuhan perusahaan dan juga melihat dari buku referensi. Juga terdapat spesifikasi jabatan yang sesuai dengan kondisi sekarang dan hal ini memudahkan pihak HRD \& GA untuk menerima pekerja baru. Se-
Tabel 1: Contoh Usulan Deskripsi Pekerjaan Operator Produksi (lanjutan)

\section{TUGAS POKOK}

a. Harian/Mingguan/Bulanan

1. Mengerjakan tugas sesuai dengan sheet produksi

2. Menunggu hasil reaksi yang sedang diproses

3. Bertanggung jawab terhadap perawatan dan pemeliharaan mesin produksi serta kebersihan area produksi

4. Menata dan merapikan raw material yang belum diproses, produk yang belum diserahkan ke gudang dan produk NCP yang ada di area produksi

5. Memberikan laporan harian kepada kepala shift

b. Insidental (hanya pada waktu tertentu saja, tidak rutin)

memberikan laporan kerusakan mesin kepada departement MEE

WEWENANG -

\section{HUBUNGAN KERJA}

a. Internal : Departemen PCL , Departemen Warehouse, Departemen MEE

b. Eksternal :

MASALAH DAN TANTANGAN KERJA

Membuat hasil porduksi sebaik mungkin sesuai dengan standar yang telah ditentukan

\section{SPESIFIKASI JABATAN}

a. Pendidikan Formal : SMK/STM Mesin atau sederajat

b. Pengalaman Kerja yang Relevan : 2 tahun di bidang produksi

c. Pelatihan/training:

d. Keterampilan khusus/skill : 
lain itu hasil analisisnya menunjukkan bahwa deskripsi pekerjaan usulan mudah untuk dipahami, sesuai dengan pekerjaan pemegang jabatan sebenarnya, dan terdapat job description secara tertulis untuk semua pemegang jabatan yang diteliti. Untuk job description secara umum, merupakan tolak ukur dalam membuat job description usulan. agar benar bahwa pekerjaan si pemegang jabatan tertentu kurang lebih sama jika dilihat secara umum.

\subsection{Evaluasi Jabatan}

Pada evaluasi jabatan sebelumnya dilakukan penentuan faktor dan sub faktor yang diteliti, dan dapat dilihat pada Gambar 2.

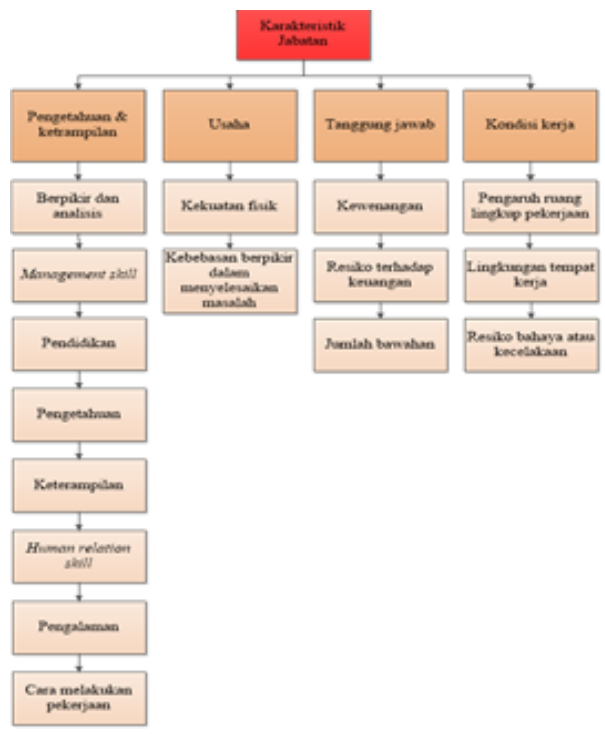

Gambar 2: Struktur Hirarki Faktor Faktor yang Mempengaruhi Karakteristik Jabatan

Hasil dari evaluasi jabatan adalah nilai relatif jabatan, yang sebelumnya dilakukan pembobotan terlebih dahulu dengan menggunakan AHP. Dari hasil pembobotan terhadap masingmasing faktor dan sub faktor dapat digunakan untuk mencari nilai skala. Setelah nilai skala didapatkan, maka dilakukan perhitungan poin untuk setiap jabatan. Hasil point untuk setiap jabatan dapat dilihat pada Tabel 2.

\subsection{Perancangan Struktur Gaji Pokok}

Berdasarkan perhitungan dengan nilai relatif jabatan dan interpolasi linear 1:2 sampai 1:4, didapatkan usulan gaji pokok terpilih berdasarkan metode interpolasi linear 1:3. Pemilihan ini karena beberapa pertimbangan, yaitu :
Tabel 2: Poin Setiap Jabatan dan Usulan Gaji Pokok Terpilih

\begin{tabular}{|c|c|c|c|}
\hline No. & Nama Jabatan & Point & $\begin{array}{c}\text { Usulan Gaji } \\
\text { Pokok } \\
\text { Terpilih (Rp) }\end{array}$ \\
\hline 1. & RED Manager & 6872.71 & Rp12,250,000 \\
\hline 2. & Production Manager & 6793.04 & Rp12,700,000 \\
\hline 3. & MEE Manager & 6341.21 & Rp9,042,352 \\
\hline 4. & QC Production Manager & 6314.35 & Rp10,650,000 \\
\hline 5. & PCL Manager & 6314.35 & Rp10,950,000 \\
\hline 6. & Area Sales Manager & 6233.04 & Rp9,800,000 \\
\hline 7. & RMPurchasing Manager & 6225.91 & Rp11,450,000 \\
\hline 8. & FGPurchasing Manager & 6225.91 & Rp11,450,000 \\
\hline 9. & HRD \& GA Manager & 6190.28 & Rp10,700,000 \\
\hline 10. & Warehouse Manager & 6163.43 & $\operatorname{Rp} 8,787,605$ \\
\hline 11. & WWT Manager & 6145.27 & Rp8,761,578 \\
\hline 12. & RED Supervisor & 5255.35 & Rp7,486,321 \\
\hline 13. & Production Supervisor & 5198.24 & Rp7,404,483 \\
\hline 14. & Warehouse Supervisor & 5109.70 & Rp7,277,598 \\
\hline 15. & HRDEGA Supervisor & 4980.52 & Rp7,092,488 \\
\hline 16. & FEA Supervisor & 4922.63 & Rp7,009,527 \\
\hline 17. & MEE Supervisor & 4890.43 & Rp6,963,392 \\
\hline 18. & IT/MIS Supervisor & 4382.13 & Rp6,234,995 \\
\hline 19. & Salesman & 4218.08 & Rp5,999,902 \\
\hline 20. & Kepala Shift Produksi & 4136.94 & Rp5,883,635 \\
\hline 21. & Kepala Shift Operator WWT & 4079.09 & Rp5,800,726 \\
\hline 22. & FG Purchasing Staff & 3795.50 & Rp5,394,349 \\
\hline 23. & RM Purchasing Staff & 3795.50 & Rp5,394,349 \\
\hline 24. & Administrasi Produksi & 3509.94 & Rp4,985,140 \\
\hline 25. & Accounting Staff & 3392.51 & $\operatorname{Rp} 4,816,853$ \\
\hline 26. & Finance Staff & 3392.51 & Rp4,816,853 \\
\hline 27. & QC Production Staff & 3175.97 & Rp4,506,556 \\
\hline 28. & Operator PCL & 3108.14 & $\operatorname{Rp} 4,409,358$ \\
\hline 29. & Teknisi MEE & 2937.42 & $\operatorname{Rp} 4,164,710$ \\
\hline 30. & Operator Production & 2893.42 & Rp4,101,659 \\
\hline
\end{tabular}

1. Presentase kenaikan yang dihasilkan, sesuai dengan kemampuan perusahaan untuk menaikkan gaji pokok yaitu sebesar $10 \%$.

2. Struktur gaji yang dipilih juga dipertimbangkan dari nilai standar deviasi yang paling kecil dan jumlah jabatan yang mengalami selisih gaji pokok sesedikit mungkin. Jika semakin kecil nilai standar deviasi, maka akan semakin mendekati nilai gaji pokok sebenarnya. Sehingga dipilih gaji pokok dengan standar deviasi terkecil.

3. Dengan menggunakan metode point factor system terdapat 8 jabatan yang mengalami kelebihan gaji pokok. Karena gaji pokok jabatan dinilai dari beban kerja yang ditanggung. Sehingga untuk jabatanjabatan tersebut, dapat dijadikan pertimbangan bagi pihak perusahaan, namun untuk 8 jabatan tersebut perusahaan menetapkan tetap menggunakan gaji pokok saat 
Tabel 2: Poin Setiap Jabatan dan Usulan Gaji Pokok Terpilih (lanjutan)

\begin{tabular}{|c|c|c|c|}
\hline No. & Nama Jabatan & Point & $\begin{array}{c}\text { Usulan Gaji } \\
\text { Pokok } \\
\text { Terpilih (Rp) }\end{array}$ \\
\hline 31. & Operator Warehouse & 2839.07 & $\mathrm{Rp} 4,023,782$ \\
\hline 32. & Receptionist & 2546.07 & $\mathrm{Rp} 3,603,910$ \\
\hline 33. & Driver & 2459.27 & $\mathrm{Rp} 3,479,519$ \\
\hline 34. & Security & 2487.48 & $\mathrm{Rp} 3,519,940$ \\
\hline 35. & Office Boy & 2344.81 & $\mathrm{Rp} 3,315,500$ \\
\hline 36. & Gardener & 2311.66 & $\mathrm{Rp} 3,268,000$ \\
\hline
\end{tabular}

Tabel 3: Rekapitulasi Usulan Struktur Gaji

\begin{tabular}{|c|c|c|c|c|}
\hline $\begin{array}{l}\text { Strultur Gaj } \\
\text { Pokkok Usulan }\end{array}$ & $\begin{array}{l}\text { Jumlah Gaj } \\
\text { Pokrok Aw al }\end{array}$ & $\begin{array}{c}\text { Jumlah Gaj } \\
\text { Polkok Terpith } \\
\text { Berdas arkan } \\
\text { Usulan }\end{array}$ & $\begin{array}{c}\text { Presenta si } \\
\text { Kenakikan }\end{array}$ & $\begin{array}{l}\text { Stancler } \\
\text { Deviasi }\end{array}$ \\
\hline \begin{tabular}{|c|} 
Gaj Pokok \\
BerdasarNR.
\end{tabular} & $R_{0} 224,510,000$ & $R 0246,605,459$ & $9.84 \%$ & $2855,086.62$ \\
\hline Usulan 1:2 & $R_{0} 224,510,000$ & $R_{0} 230,489.910$ & $206 \%$ & 3.036 .675 .11 \\
\hline Usulan $1: 3$ & Rp $224,510,000$ & Rp247,495,081 & $10.24 \%$ & $2815,093.92$ \\
\hline & & & 27.8 & \\
\hline
\end{tabular}

ini yang diberlakukan perusahaan. Karena tidak mungkin terdapat jabatan yang diturunkan gajinya tanpa perundingan panjang dari perusahaan terlebih dahulu.

4. Gaji pokok yang paling minimum tidak boleh dibawah Upah Minimum Regional Kabupaten Bekasi untuk industri sejenis pada tahun 2015.

Hasil rekapitulasi usulan struktur gaji pokok dapat dilihat pada Tabel 3. Sedangkan untuk hasil poin dan usulan gaji pokok terpilih dapat dilihat pada Tabel 2.

Setelahnya dilakukan perhitungan garis regresi linear dan uji asumsi klasik. Variabel $\mathrm{Y}$ adalah gaji pokok terpilih dan variabel $\mathrm{X}$ adalah poin. Dari uji asumsi klasik didapatkan bahwa semua uji sesuai dengan kriteria. Hal ini berarti bahwa data yang diuji dapat menggunakan metode regresi linear. Sehingga dapat dibuat grafik garis regresi struktur gaji pokok usulan dan struktur gaji pokok saat ini yang dapat dilihat pada Gambar 3.

Grafik ini berguna bagi pihak perusahaan dalam menentukan poin dan gaji pokok bagi pekerja baru nantinya. Hasil dari usulan struktur gaji pokok terpilih juga disetujui oleh pihak perusahaan dengan menggunakan struktur gaji pokok usulan, setiap jabatan akan terlihat perbedaannya sesuai dengan bobot pekerjaan masingmasing. Hal ini karena struktur gaji pokok usulan menggunakan metode point factor system, dimana metode ini dalam aplikasinya banyak digunakan dibandingkan metode-metode struktur gaji pokok yang lain. Namun, struk- tur gaji pokok dengan metode ini juga bukan yang terbaik, masih terdapat kekurangan juga. Tetapi jika dibandingkan dengan struktur gaji pokok saat ini, struktur gaji pokok usulan dapat dikatakan lebih baik karena struktur gaji pokok saat ini tidak menggunakan metode tertentu dan tidak ada strukturnya, hanya menurut penilaian masing-masing setiap jabatan dan gaji pokok industri sejenis serta UMR Kabupaten Bekasi. Selain itu metode point factor system lebih terbuka dalam penilaian dan lebih adil mengenai faktor dan sub faktor apa saja yang ingin digunakan untuk penilaian.

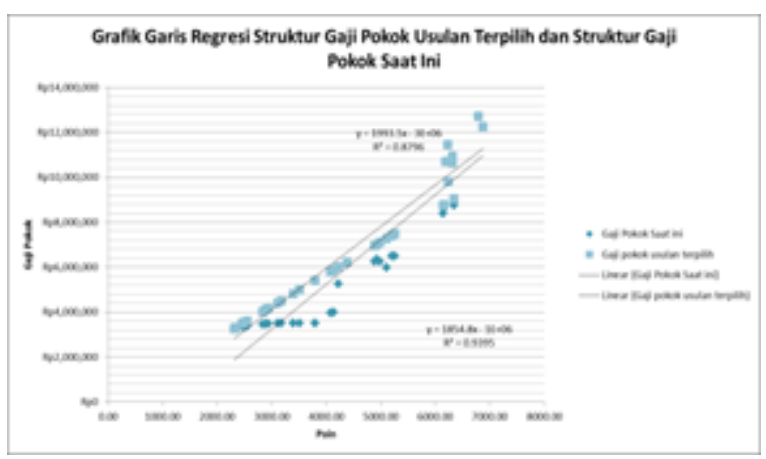

Gambar 3: Grafik Regresi Struktur Gaji Pokok Saat Ini dan Struktur Gaji Pokok Usulan Terpilih

\section{Kesimpulan}

Berdasarkan penelitian yang telah dilakukan dapat dibuat kesimpulan, yaitu :

1. Analisis jabatan yang telah dilakukan menghasilkan job decription usulan dan job specification usulan yang dapat diterapkan oleh perusahaan tempat penelitian.

2. Evaluasi jabatan yang telah dilakukan dengan menggunakan metode point factor system, menghasilkan struktur gaji pokok usulan bagi perusahaan.

3. Berdasarkan struktur gaji pokok saat ini, gaji pokok paling minimum perusahaan tempat penelitian adalah berdasarkan Upah Minimum Regional Kabupaten Bekasi tahun 2015, struktur gaji pokok usulan yang terpilih adalah berdasarkan interpolasi 1 : 3 dengan presentase kenaikan gaji pokok sebesar $10,24 \%$, dan terdapat 8 jabatan yang mengalami kelebihan gaji pokok jika berdasarkan metode point factor system. 


\section{Daftar Pustaka}

Admin., (2010). Struktur dan Skala Upah, [Online], Diakses dari: http://www.hukumonline.com/ [2015, 8 September].

Dessler, G. (2006). Manajemen Sumber Daya Manusia. (10th ed.). Jakarta: PT Indeks Putri Media Kembangan.

Haris, M. (2014). Pedoman Pengupahan Industri Manufaktur. Jakarta: PPM Manajemen.

Iwan., \& Octavia, T. (2013). Perancangan Perbaikan Sistem Pembelian Bahan Baku di PT FSCM Manufacturing. Jurnal Titra, Vol. 1 (1), 83-90.

Marwansyah. (2010). Manajemen Sumber Daya Manusia. Bandung: Alfabeta.

Mathis, R., \& Jackson, J. (2006). Human Resources Management. (10th ed.) . Jakarta: Salemba Empat.

Sugiyono. (2009). Metode Penelitian Kuantitatif Kualitatif dan RED. Bandung: Alfabeta.

Sukwadi, R. (2014). Perbaikan Struktur Gaji Dasar Karyawan Berdasarkan Hasil Analisa dan Evaluasi Jabatan. Spektrum Industri, Vol. 12 (1), 93-104.

Sukwadi, R., \& Gerald, F. (2010). Usulan Perancangan Sistem Kompensasi dengan Menggunakan Point Rating System (Studi Kasus: PT Pabrik Kaos Aseli). Jurnal INASEA, Vol. 11 (1), 16-25.

Suprianto, J. (2002). Penilaian Kinerja dan Pengembangan Karyawan. Jakarta : BPFE.

York, K. M. (2010). Applied Human Resources Management: Strategic Issues and Experiential Exersices. California: SAGE Publications, Inc. 